\title{
Relationality, Resistance and Mimicry: Towards an Alternate Discourse of Violence and Victimhood from the North East of India
}

\author{
Ridhima Tewari ${ }^{1} \&$ Pragnya Parimita Chayani ${ }^{2}$
}

${ }^{1}$ Assistant Professor, Department of Humanities and Social Sciences, IIT Dharwad. ORCID: oooo-0oo3-3073-4948. Email: ridhima@iitdh.ac.in

${ }^{2}$ Ph.D. Scholar, Department of Humanities and Social Sciences, Department of Humanities and Social Sciences, IIT Dharwad. ORCID: 0ooo-0oo2-2406-2674.

Email: pragnya.chayani@gmail.com

\begin{abstract}
The present paper seeks to complicate and contribute to the discourse around human rights (HR), specifically the violence inflicted, and the radical reconstructing of victimhood, by employing literary narratives from North-East of India. Such an attempt at broadening perspectives on HR is undertaken with the aid of Judith Butler's analysis of relational nature of the self, as well as the reconceptualizing of mimesis in feminist and postcolonial thought (as discussed by Rey Chow and others). While Butler focuses on mourning and its transformative potential from narcissism to the outside/other, emphasizing on the primacy of the body, Rey Chow shows how theorists such as Luce Irigaray and Homi Bhabha have revived mimesis, employing it as mimicry for subversive purposes. This paper utilizes literary responses from the North-East of India- poems written in the backdrop of military violence in these states- for arriving at an alternate set of responses to violence. Such responses question the very ontology of human rights- why some humans matter less, why some lives are always already neglected- while investigating the projection of sacrifice, victimhood, and the resistance that the mimic-victim provides from within the framework of subordination.
\end{abstract}

Keywords: Human Rights, Violence, Relationality, Mimicry, Resistance

I am a Jew. Hath not a Jew eyes? Hath not a Jew hands, organs, dimensions, senses, affections, passions? Fed with the same food, hurt with the same weapons, subject to the same diseases, healed by the same means? If you prick us, do we not bleed? If you tickle us, do we not laugh? If you poison us, do we not die?...Yes, a Jew has eyes but so does a pig. (Kohen, 2007, p.7)

Shylock's array of questions from The Merchant of Venice (160o) open legitimate arguments for debating and critiquing the regime of human rights- who is entitled to human rights and who is not, why are some more vulnerable as humans, while others have more human rights at their disposal. Recent years have seen innumerable instances when such debates have emerged in the public sphere. The '\#BlackLivesMatter' movement is an example of this public questioning in recent times, propelled largely by protests in the digital world. It did trigger counter responses such as 'AllLivesMatter' that was in turn widely criticized for its diluting of racial discrimination

(C) AesthetixMS 2019. This Open Access article is published under a Creative Commons Attribution Non-Commercial 4.0 International License (http://creativecommons.org/licenses/by-nc/4.o/), which permits non-commercial re-use, distribution, and reproduction in any medium, provided the original work is properly cited. For citation use the DOI. For commercial re-use, please contact editor@rupkatha.com. 
and the violence inflicted on black lives even today. Undoubtedly, the \#BlackLivesMatter movement highlighted human rights abuses, the dehumanizing of black people by white supremacist, especially in the US. This expose of dehumanization also interrogated the politics interwoven in granting human rights to some, while devaluing lives of some others.

With French Revolution (1789-1799), and the subsequent socio-political upheaval in France and French colonies, human rights or rights of man were first established (liberty, equality and fraternity). These rights came to denote a, "...sense of universality, that all persons by virtue of being human have certain common entitlements..." (Falk,2004, p.19). The emergence of 'right' can in fact be traced back to "late middle ages" (Griffin, 2001, p.309). The twelfth and thirteen centuries' use of the Latin word "ius" (Griffin, 2001, p.309) is the precursor to the contemporary word 'right'. It was also believed that man was created with rationality and morality to act upon and to claim something as his right. This rationality and moral agency were also valued during the Renaissance and were central to the seventeenth and eighteenth-century political thoughts. The Enlightenment project made further investments into of human dignity, reason and freedom. In 1948, UN General Assembly accepted UDHR (Universal Declaration of Human Rights). With debates, disputes and movements pertaining to human rights across cultures, there was ultimately an emergence of a "political culture around" (Nayar, 2012, p.3) it. These mass engagements paved a way for human rights to enter other domains - philosophy, literature, media, socio-political movements, etc. Louis Henkin (1989) defines human rights in the following way:

Human rights are not the equivalent of justice, or "the good society," or, as some think, democracy, although the human rights idea is related to all of these...The individual counts, and counts independently of the community. The idea suggests equality of human beings, not hierarchy among them. It implies that values of liberty and autonomy are sometimes more important than values of order. (p.11)

Since the time there have been advocacies of human rights, there have also emerged instances of its violation, as in colonization, slavery, violation of indigenous rights or treatment of Australian stolen generation, women, racism, and religious beliefs (Falk,2004,p.19) etc. The post 9/11 era has witnessed "a legion of human rights abuses" (Anker, 2015, p.38), which resulted in the United States waging 'war against terror'. The United States' anti-terrorism laws, on one hand, were vividly security-concerned and on the other, showed undeniable violations of human rights in unleashing more terror and human suffering. Contemporary global problems like terrorism, racism, genocide, homophobia etc. have put human rights issues under the scanner. Rather than reading human rights and its representations in literature as a goal in itself, this paper attempts to focus on issues of human rights from the perspective of human ontology, grieving, communal existence, violence and ethical responses to it.

The Post 9/11 era has seen considerable scholarly focus on human rights and Judith Butler's contribution in this regard is quite significant. Judith Butler (2008) investigates the very understanding of what it is to be human, the relational nature of existence, the precarity of life via human bodies and the need to arrive at an egalitarian and communal ethics of rights. She writes in "Performativity, Precarity and Sexual Politics":

... "precarity" designates that politically induced condition in which certain populations suffer from failing social and economic networks of support and become differentially exposed to injury, violence, and death. Such populations are at heightened risk of disease, poverty, starvation, displacement, and of exposure to violence without protection. Precarity also characterizes that politically induced condition of maximized vulnerability 
and exposure for populations exposed to arbitrary state violence and to other forms of aggression that are not enacted by states and against which states do not offer adequate protection. (Butler, 2009, p.ii)

This, therefore, creates a need to interrogate the political framework of human rights, violence, and its articulation. It is here, this paper claims, that literature could assist in redefining the very ontology of human rights, the relational nature of the self, the body and power. The paper would employ Judith Butler's views on grieving or mourning to study narratives of violence from the North-East, as well as draw upon her deliberations on community, inclusiveness and performativity as discussed in Butler's(2015) Notes Toward a Performative Theory of Assembly Butler's essay "Violence, Mourning, Politics" (2008) forms the second chapter of her book, Precarious Life: The Powers of Mourning and Violence. Butler here strives to show the political nature of lives, vulnerability of bodies in socio-political context and posits that a depolitical/private understanding of the act of mourning leads to an ethically compromised understanding of human existence, grief and the violence inflicted. She enquires into what constitutes the human (Smith, 2004, p.256) and argues that certain lives in our cultures are constructed as more mournable than others. In Notes Toward a Performative Theory of Assembly Butler(2015) asserts:

The body politic is posited as a unity it can never be. Yet, that does not have to be a cynical conclusion... The point of democratic politics is not simply to extend recognition equally to all of the people, but, rather, to grasp that only by changing the relation between the recognizable and unrecognizable can (a) equality be understood and pursued and (b) "the people" become open to a further elaboration. Even when a form of recognition is extended to all the people, there remains an active premise that there is a vast region of those who remain unrecognizable, and that very power differential is reproduced each time... (p.4-5)

Valuing every life, she appeals for a universalism, invites an ethical and communal understanding into responses to violence, and intends to redefine the extremely individualistic understanding of human rights. Closing the Notes Toward a Performative Theory of Assembly with musings on "the good life", Butler (2015) interlinks this kind of life with critique, resistance and a connect with others: "If I am to lead a good life, it will be a life lived with others... whoever I am will be transformed by my connections with others, since my dependency on another, and my dependability, are necessary in order to live and to live well" (p.218). Similarly, there are three main axes on which formulations from her essay "Violence, Mourning, Politics" appear: i) Understanding the relational nature of human lives, ii) grieving or mourning provides an avenue for understanding the bodily relationality and community ethos and iii) an acceptance of relational nature of the self and community ethics involved, could in turn lead to egalitarian, ethical responses to violence.

The need to arrive at a communal/cultural understanding of violence, away from the reductive approach of the political, and to understand the inclusive-exclusion of individuals from the political structures has been further contributed to through the incorporation of desire and its mimetic potential. Rey Chow (2006) in the essay, "Sacrifice, Mimesis, and the Theorizing of Victimhood" establishes a relationship between human existence, victimhood, sovereign power and 'law' as defined by Giorgio Agamben (p.132). Chow analyses Agamben's postulations on the contradictions of being constituted as a subject by the political power of the State, which also leaves the individual powerless (s/he can be killed but not sacrificed as the homo sacer). The resultant nihilism, becomes the underlying way of life, as the basis of law is primarily nothing 
except an arbitrary structuring of power over what Agamben calls 'bare life' (p.131). Chow however 'resurrects' such a human-victim, by engaging with the radical possibilities of mimesis as a deliberate act. Seeking to offer a discursive turn to the concept of victimhood, she reopens Luce Irigaray's notion of mimetic resistance in the light of gender discourse, and Homi Bhabha and Franz Fanon's 'mimicry' in order to show that mimesis has always been a preferred medium of resistance. Referring to mimesis as "a coping mechanism and survival tactic", Chow (2006) underlines the indeterminacy, substitution, and desire involved that turn mimesis into mimicry:

Between the (positive) condition of wanting to imitate the white man and the (negative) condition of self-loathing and self-abatement, lies what may be seen as an entire range of epistemic and representational possibilities, possibilities that infinitely enrich the theorization of postcolonial subjectivities... Much like Irigaray's self-conscious mimicry, the colonized's desire here makes way for a resilient, because mobile framework for imagining alterity from within subordination. (p.140)

Additionally, Chow (2006) also contests and revisits Agamben's "stringent critique of the notion of sacrifice" that aligns with absolute nihilism and unrepresentability of the violent power schemes. Chow (2006) does so by instead highlighting the inescapable interlink between mimesis and sacrifice, the inevitability of exchange, performance, substitution in establishing of power structures and socio-political relationships. This, according to the theorist, ultimately questions "the finality and nonegotiability of victimhood through behavioral and psychic flexibility" (p.140).

In what follows, we explore possibilities of broadening the discourse around Human Rights, Violence and Victimhood by positing both a relational nature in which the self exists, and by assigning possibilities of mimicry and sacrifice to the conventional 'victim' in literary narratives. The literary narrative, in such an exercise, also becomes a site of countering the 'aesthetic' approach to depicting violence that assumes its fundamental unrepresentability.

Literature has an important role to play in arriving at an ethical and communal understanding of human lives and the violence faced. Prof Pramod K. Nayar (2012)in his introduction to the book, Writing Wrongs: The cultural construction of Human Rights in India best summarizes the relationality that exists between human rights and literary narratives:

A dead woman strung on a pole, being carried like a dead animal by army personnel somewhere in the northeast of India. The naked women protesting against rape by army men in Manipur...These scenes (both images and narratives) are sites where victims put forward themselves, their bodies, lives and deaths as testimony to the absence of Human Rights...for many people across the world...When victims present themselves...When reporters, scholars and commentators narrativize...HR finds a language. (p.o1)

Prof Nayar (2012) argues that his book seeks “...to represent social wrongs and abstract ideas of justice" by "paying attention to ...cultural representations" where "...genres and media as collectively producing a culture of rights."Literature that tells tales of violation of human rights may not have efficacy to appeal to the judiciary, but does, according to Prof Nayar (2012), carry possibilities of moving the collective conscience and ethical imagination of a people. Simultaneously, these narratives written by victims and survivors are backed up by "real socialhistorical condition" (Nayar, 2012, p.2) where "private grief folds into a collective cultural memory" (Nayar, 2012, p.5). Prof Nayar (2012) also supports Goldberg's assertions that these texts in fact create "a deeper consciousness" (p.5) among readers and hence promote an "ethical turn in narrative studies" (Nayar, 2012, p.2). 
It is here that poems from the North-East region of India offer an alternate discourse on some of the foundational aspects of rights, their violation and in carving out ethical responses to these violations. The paper undertakes an analysis of nine poems which are "The Land of The Half-Humans" by Thangjam Ibopishak Singh (2003), "Body" by Robin S. Ngangom (2007), "I want to be killed by an Indian Bullet" by Thangjam Ibopishak Singh(2003), "To Pacha” by Robin S. Ngangom (2006), "What Poetry Means to Ernestina in Peril"by Mona Zote(2005), "Story of a Dream” by Yumlembam Ibomcha Singh(2003),"My Invented Land” by Robin S. Ngangom(2008), "Poem for Joseph" by Robin S. Ngangom (2008) and finally, "Sister" by Saratchand Thiyam(2014). The analysis is undertaken based on two major themes, (1) mimicry and resistance and (2) the concept of Nation/community and violence. The body as a site of violence, resistance, mimicry and performance is omnipresent across both these approaches to the literary pieces.

All of these poems are written on the backdrop of insurgency in the North-East region of India. The paper tries to take the analysis beyond simplistic depiction of AFSPA-affected lives (Armed Forces Special Protection Act), instead approaching the complex issue of violence and human rights through: (a) Establishing relational nature of the self, where the individual is not an isolated entity, rather a part of a community and violation of HR on her/him is understood in the realm of violence against the community at large (Butlerian framework). Hence, mourning or grieving the loss is also not a private act, but in fact, encompasses a community; and (b)Countering charges of passivity often assigned to the 'victim' as s/he shifts towards an ethical response to violence, through Rey Chow's(2006) deliberations on the mimetic potentials of 'victimhood'.

The North-East region of India consists of the states of Arunachal Pradesh, Assam, Manipur, Meghalaya, Mizoram, Nagaland, Sikkim and Tripura. Like all categories, the 'NorthEast' does not represent a homogenous group, as evidenced by the diverse number of languages spoken, social-cultural practices and tribal/religious affiliations. The literature from this region however, does predominantly talk about terror, altered landscape, subjugated lives, belonging and in particular, instances of violation of human rights. Written both in regional languages and English, this heterogeneous literature, forms an important part of the regional literature of India. Lives affected by AFSPA (Armed Forces Special Protection Act) ${ }^{\mathrm{i}}$ dominate most of these narratives.

AFSPA was extended to six Indian states: Assam, Arunachal Pradesh, Nagaland, Manipur, Meghalaya and Jammu \& Kashmir under section 3 of AFSPA. The Centre withdrew it in Meghalaya on April 1, 2018. These places were declared as disturbed areas by the government primarily due to disputes between communities pertaining to racial, linguistic and religious differences, and subsequently saw considerable military control. Cases of the Army intervening into socio-cultural life of people and extending into violence were subsequently reported, leading to mass protests. Irom Sharmila's hunger strike, and the nude public parades of women from Manipur, occupied front pages of media discourses for decades. Disturbed political ambiance, marginalization, neglected ethnicity, the trauma of rape, loss of lives have produced a poignant oeuvre of regional literature. The scholar Yumnam Devi (2014) provides an insight into the writers of this region:

... [they] have witnessed growing ethnic aggressiveness, secessionist ventures, cultural and religious bigotry, the marginalization of minorities and the poor, profit and power struggles in government and as a natural aftermath of these, the banality of corruption and the banality of terror. (p.205) 
Literature addresses inadequacies of the political framework by turning towards issues of human ontology, grieving and violence. It also becomes a site of mimetic performance by the victim who invokes, documents, as well as alters the very strategies of violence. Mimesis implies a replication of reality, while simultaneously holding up possibilities of subverting those very structures of the real through mimicry. Literary narratives of human rights and violence, this paper claims, are replete with acts of mimesis. The texts under analysis are not just records of passive witnessing or violence, but involve mimic-performances that attempt to subvert strategies of discrimination and violence, in turn redefining victimhood. Mimicry is undertaken in these poems in different ways.

"The Land of Half-Humans"(Singh,2003) provides an alternative narrative to the popular myth of Shakunias a suffering villain, where human beings are reduced to heads and torsos. The narrative offers a different setting which shocks, with its singular focus on figures with only heads or torsos. By creating an anonymous land of anonymous people without a head, the poem is a ridicule of hierarchy and also an act of resistance. A land that remains nameless since humans are half-humans, also hints at a land which is dehumanized and reduced to mere corpses. The poem also conjures up images of the nation where none is really human. Since the land is essentially nameless and bodies are diminished to heads and torsos, they are also no longer available as subjects who can be victimized. Hence, the poet has instilled agency in the dismantled bodies and has denied perpetrators of violence the power to shame or scare such 'inadequate' subjects.

The poem "Body" by Robin S.Ngangom (2007), a poet from Manipur complicates issues of bodily subversion through violence. The poem is an attempt to resist victimization in a land where an individual is reduced to a vulnerable body. Simultaneously, the body here also stands for something larger for the violence-resisting community that refuses to surrender: "Deny eyes and fingers are already on the keys" (Ngangom,2007). The body, the narrator tells us, is "Adam's child" which can conceal "intimate evidence", while performing both conformity and resistance.

Similarly, "I want to be killed by an Indian Bullet"(Singh,2003) extends obedience to arbitrary forces emerging out of the State to the point of comical subversion. In such a land, the speaker at gunpoint claims to be a patriot who wants to die only by an Indian bullet. This wish is a mockery of the powers that reduce humans to mere toys, which on the one hand are incapable of securing human rights, while on the other, perpetrate violence against some. Written on the backdrop of violence inflicted on people from North-East region of India, specifically, "I want to be killed by an Indian Bullet" the poem mimics strategies of powers by accepting the arbitrariness of death. It additionally captures and mocks excessive patriotism of the "agents" of the State, which exposes the inclusive-exclusion practised by the State. The last line of the poem mentions 'Bharat' when 'India' is used throughout the poem, thereby intensifying the 'performance' of the victim-patriot. The guns are foreign, the laws are arbitrary and the dehumanized person is farcically a patriot.

In a similar vein, Robin S. Ngangom's (2006) “To Pacha” is a text that mimes and mocks the violence around. The poet revisits the figure of Pachaii who is referred to as a 'lunatic' andan 'artist'. He is a madman, a mimic, yet, a rebel, “a comrade” who spoke boldly. Robin S. Ngangom's Pacha resembles the hyper-curious narrator of "I want to be killed by an Indian Bullet," who seeks to know the very method of his death. The poet tells us very little about Pacha, except that his laughter rang loudly in the faces of his oppressors. Pacha's rebellion lies in his desire to 'experience' freedom, in wishing to tread on the very grass of his 'land' rather than in eulogizing the greatness of a nation. Pacha refuses to make facile endorsements of nationhood or belonging to a land. His pure aspirations and the desire to be free reflect in this refusal to adhere, and lead 
to his ultimate denial of the victim-position. Little wonder then that Pacha today is a forgotten hero of a neglected place.

A poem such as "What Poetry Means to Ernestina in Peril" by Mizo poet Mona Zote (2005) also plays with a mimetic framework. The poetic voice asserts: "Ignoring the problem will not make it go away"(Zote, 2005), implying an acceptance of reality and a display of it as a means of survival. At the same time, the poem posits the individual as being a part of a larger community that has "been bombed silly out of our [their] minds" (Zote, 2005),by linking the mysterious Ernestina to her surroundings. The "rustle of Ernestina's skirt"(Zote, 2005) is hence, a reminder of random killings, lawlessness and how "your neighbor is kidnapped by demons" (Zote, 2005). Ernestina's identity is not her own and her history is linked to that of the community as well. Thus, the HR discourse here focuses on the violation of individual rights and in doing so, shows its interconnections with the community at large. "She will rise with a look of terror too really real to be comical", we are told, an exclamation which nonetheless implies that she will replicate the reality in order to create a mockery out of it.

A lucid account of mimicry is visible in Manipuri poet Yumlembam Ibomcha Singh ${ }^{\mathrm{iii}} \mathrm{s}$ (2003) poem "Story of a Dream" where the narrator dreams of a bullet as a silky caress from a young woman, making him happy. The poetic narrative is woven out of a series of sensuous images that conceive violence and threat as pleasurable experiences. The bullet shot into mouth becomes a juicy grape and the continuous firing that brings mass destruction is dreamt as a rain of raisins, almonds and fruits. A painful annihilation is symbolically turned into a picture of happiness, smiles and good health as in "women returning, greeted each other cheerfully"(Singh,2003). The dream setting allows the poet to mime real episodes of violence and turn them into mimicry through radical responses. The darker sub-text of the poem is perhaps the fact, that like a dream, happiness here is a myth. The neglect and sustained rights struggles set against the loss of lives and a silent culture, bring one to Judith Butler's (2008) question "what makes for a grievable life?"(p.10).

Mimicry, repetition, stoicism as acts of resistance are also visible in "My Invented Land" by Robin S. Ngangom (2008).The poem problematizes the idea of 'belonging', 'boundaries', citizenship and 'community aspirations'. The 'I' here is a witness to the tortures of the troubled community. The poem's narrator is a wise yet suffering prophet much like Tiresias, belonging to a community of unequal citizens, abandoned by the nation-state. References to the lost "alphabet" of their language, "decrepit libraries" (Ngangom,2008), youngsters struggling with substanceabuse, and to hairstyles of native women are all emblematic of the various ways in which the very idea of a 'homeland' is slipping away. The narrator finds resolve in declaring that his "home is a gun" (Ngangom,2008), captured in "a sonnet about body counts", the bodies being "undoubtedly raped" (Ngangom,2008). The last line of the poem: "definitely abandoned in a tryst with destiny"(Ngangom,2008) is a reminder and mimicry of Prime Minister, Jawaharlal Nehru's speech at Independence in 1947, a speech that claimed of new histories, new destinies awaiting the newborn nation.

Returning to Butler's (2008) essay, "Violence, Mourning, Politics", the philosopher focuses on what she terms as a "relational" bond that ties an individual to her/his community. Reopening the subject of human ontology, Butler (2008) presents a case for an "I" that is always, inevitably interlinked with a 'You', the latter also entailing a plural subjectivity of the community. This correlation is established through an underlining of emotions that place us "beside ourselves"motions such as "sexual passion, or emotional grief, or political rage". Extending this relationality at the level of the body, Butler(2008) highlights the paradox of how though bodily autonomy 
remains integral to individual rights and living, the body always exists in a "public dimension"(p.15). This further problematizes an individualistic, private and depoliticized understanding of bodily existence, violence, loss, emphasizing instead communal contexts and responsibilities. As Butler (2008) points out, such an understanding of the body, communal ties, vulnerability and 'passions', is especially helpful in studying the political status of minorities and neglected groups.

The literary narratives from the North-East also prove to be a fitting site for expanding/reconceptualising human rights and public/private subjectivities. For instance, a poem like "The Land of the Half-Humans" is an attempt at constructing alternate myths of violent episodes, narratives that employ complex discursive strategies for countering dehumanizing of certain communities and lives. Thankgjam Ibopishak Singh (2003) conceives of a land with halfhumans, bodies without head for six months, and heads with no bodies for the rest of the year. Claiming "it's not a folktale" (Singh, 2003), the narrator depicts the land he claims to have visited. Blurring the lines between social reality, metaphor and folk-tale, the poem employs dark humour to expose hierarchies within the half-human physiognomy. The narrator compares the feeding, talking, drinking head with "Bhima gorging" (Singh, 2003) for six continuous months. This is contrasted with the excreting body that performs the wretched task for the rest of the year, and is compared to "Shakuni suffering" (Singh, 2003). Women and children, the narrator claims, also exist similarly, with women's mouths also spitting children out. It is significant that the women here "speak the language of men", and have no teeth.

By establishing a hierarchal relationship within the human physiognomy itself, the poet offers a powerful critique of the land with its naturalised scheme of discrimination. The privileged heads that occupy the land for half the year, we are told, eat up "the earnings of the body's sweat of six months". The dark satire is replete with suggestions of a successful democracy in the land, despite inequalities of life, work and wealth, besides the complete absence of names. "Political rights" the narrator says, exist, as do men far more privilege than the god of wealth, Kuber. The egalitarianism of such a land is further subverted by the fact that the head speaks and is heard, while the body only emits a voice that goes unrecognised, unacknowledged.

A similarly pronounced focus on the body is seen in Robin S Ngangom's poem "Body". Ngangom's (2007) poem seems to echo Butlerian assertion of a certain dispossession of the self through the body, the latter's vulnerability and inevitable existence within "certain social and political conditions" (Butler, 2008, p.18). The poet declares that "The body is never free of the human condition"(Ngangom,2007), linking it with trappings of the conditioned mind, as well as with deep emotions, much like Butler's employment of mourning for understanding of the relational nature of self and the other. Positing the body as a site for unpacking the working of "moral and philosophical apparatuses", the poet highlights its inherent vulnerability. From "serial killers" (Ngangom,2007), to "rapists in uniform" (Ngangom,2007), the body is threatened as site of cultural bonds, passions, evidence of violation, as well as of resistance. The closing lines of the poem hint a movement from the individual body to the body politic, by describing resistance that the body offers:

"Sever an organ but the tongue takes over,

Remove a hand and the foot starts painting,

Deny eyes and fingers are already on the keys." (Ngangom, 2007)

The poem contributes to a discourse of relationality between the individual and the community by locating the essentially political nature of the body. The ensuing violence within such a 
framework results in a nuanced narrative of resistance, one that acknowledges loss and promotes healing and acceptance.

The idea of a homeland, a community, is a recurring presence in Ngangom's poetry. In attempting to articulate and redefine notions of 'belonging', the poetic voice in Ngangom's verses shifts between that of the wise and suffering Tiresias (as in "My Invented Land"), or of the dehumanized, 'pissing animal' as in the poem, "Poem for Joseph" (2006). However, issues of community, agency, heritage, and power are complicated as Ngangom implicates his people in the fortunes of Manipur. The description of the abject violence goes hand in hand with a painful critique of his own 'callous tribe' in “dog-eat-dog Imphal” (Ngangom, 2006). The name 'Joseph' recalls the biblical figure of Joseph who was sold to slavery and hence exiled from his own land. This exiled life of Joseph finds contemporary relevance in the homelessness of the poet's tribe, which is struggling to survive in the face of violence, and to retain emblems of a home. The individual struggle of Joseph is inevitably linked to that of the displaced community at large, as the voice exclaims:

"But I need a homeland

Where I can recognize myself".(Ngangom,2008)

"Sister", a poem by Saratchand Thiyam(2014) offers a divergent yet communal understanding of violence faced. The narrative is an oblique sketch of an afternoon scene, experienced by a "we" who no longer relate to the landscape. While the narrator warns "sister" from venturing out in the hard rain, references to disturbed homes, "incoherent babies"( Thiyam,2014), and a road reverberating with the stamping of strong boots, construct a community under attack. The onslaught of violent forces on the community is sealed through a comparison of courtyards with the 'MangarakKanbi'- a gorge in Manipur known as a site for bodies of those dying unnatural deaths.

Another text that critiques and reinvents notions of life, death, oppression and belonging through dark humour is famous Manipuri poet, Thankgjam Ibopishak Singh's(2003) "I want to be killed by an Indian Bullet". Much like "The Land of the Half-Humans", Singh's "I want to be killed by an Indian Bullet" also plays on the absurdity of life and death, reopening questions around patriotism and belonging. The narrative breaks down such critical claims into a set of farcical questions between the five powerful "avatar of might"(Singh,2003) who have come to kill, and the fugitive-narrator. Having arrived to kill on an "auspicious" day, the leaders accuse the fugitive of being either a "poet", or a "seer" or a "madman". The narrator on his part displays a deep curiosity to know how he is to be killed, and on finding out he would be shot, requests to be shot "with a gun made in India"(Singh,2003). The very mention of Bharat from the "madman" is disturbing to the assassins, who no longer wish to kill him, but depart without accomplishing their mission.

The startling turn of events is accompanied by a warning to the narrator "Don't ever mention Bharat to us"(Singh,2003), and is off-set by earlier retorts where the five great agents had rejected Indian guns asserting "India cannot even make plastic flowers"(Singh,2003).The significance of nomenclatures- from India to Bharat, the appropriation of patriotism by "They [who] create men; also destroy men at whim" "(Singh,2003), reopens questions of who are deemed as rightful citizens, who 'belong', whose rights matter and why some deaths become insignificant.

"What Poetry Means to Ernestina in Peril" by Mona Zote (2005) also offers a graphic representation of violence with the assertion that "...Poetry must be raw like a side of beef, should 
drip blood, remind you of sweat and dusty slaughter" and having done that, translates into a rich specimen of the HR discourse.

A discursive turn in such stories of hierarchal rights is offered by poems like "Story of a Dream”. Manipuri poet Yumlembam Ibomcha Singh's (2003) poem assimilates the movement from 'I' to 'our', with a conscious focus on the corporeal dimensions of pain and pleasure. Beginning with the "I" who narrates an individual dream, the poem builds an alternate landscape beyond blood spattered terrains for the community at large. In such a landscape of violence, death, gun-fire lead to sensual experiences for the body- from the bullet feeling like a gentle caress on the cheek, to gun-fire spouting countless fruits before the narrator, to the sound of the guns echoing violins and sitar. In such a dream, it is the community that begins to love joyfully again. While young women walk with grace and beauty, the old revive their spirits again, and all "laughed in unison"(Singh,2003).

The narrator does not wish to wake up, acknowledging the fragility of such a dream. Binding the bodily with the community, admitting loss and upholding ethical ties, the narrative becomes a critical example of reinventing frameworks of violence studies.

Primarily built on an acceptance of lost lives and landscape, these poems perform mourning as a political act that reaches out to a larger "we". The "we" however is presented as an evolving community of 'precarious' bodies, faced with complex forces of loss of people and property, disillusionment with the nation-state, the loss of cultural symbols and heroes, and a gradual fatigue and acceptance of sustained neglect as unequal citizens. The literary pieces discussed here also circumvent standard stereotypes of bare narrativization, instead re-imagining victimhood as replete with mimetic possibilities. In repeating, conforming and recording the very strategies of violence, the texts themselves perform and expose the illegitimacy of oppressive frameworks governing lives in the North East. Such poetic narratives, while negotiating human rights violation, justifiably establish the centrality of the bodily, thereby interlinking the individual with the communal, the complex workings of State law and with 'bare life', while creating a space beyond blatant violence of the AFSPA regime.

\section{Notes}

iAFSPA gives armed forces the power to maintain public order in "disturbed areas". They have the authority to prohibit a gathering of five or more persons in an area, can use force or even open fire after giving due warning if they feel a person is in contravention of the law. If reasonable suspicion exists, the army can also arrest a person without a warrant; enter or search premises without a warrant; and ban the possession of firearms.(The Hindu Net Desk,2018)

ii Pacha is a reference to Pacha Meetei, the Sahitya Akademi winning writer from Manipur. He died a lonely and difficult death from alcohol addiction and poverty. He was notorious for having independent thoughts, hence, beinglabelled a mad man.

iii $\mathrm{He}$ is a recipient of the Manipur State Kala Akademi Award for literature (1974), the Sahitya Akademi Award (1991) and the Sahitya Akademi Translation Prize (2008). 


\section{References}

Butler, Judith.(2015).Notes Toward a Performative Theory of Assembly.Retrieved from https://www.amazon.com/Performative-Assembly-Flexner-Lectures-College/dp/o674967755

Butler, Judith.(2009) .Performativity, Precarity and Sexual Politics.Antropólogos Iberoamericanosen Red,4(3),i-xiii. Retrieved from http://www.aibr.org/antropologia/o4vo3/criticos/o40301b.pdf

Butler, Judith.(2008) .Violence, Mourning, Politics. Studies in Gender and Sexuality,4(1),9-36. Retrieved from http://dx.doi.org/10.108o/15240650409349213

Devi, Yumnam Nirmala.(2014).Locating Trauma in Saratchand Thiyam's Sister and other poems. International Journal of English Language, Literature in Humanities, II(VII), 204-215.Retrieved fromhttp://ijellh.com/OJS/index.php/OJS/article/view/203

Falk, Richard.(2004).Human Rights. Foreign Policy, 141, 18-28.Retrieved from http://www.jstor.org/stable/4147546

Griffin, James.(2001) First steps in Account of Human Rights.European Journal of Philosophy,9(3),306327.Retrieved from https://onlinelibrary.wiley.com/doi/abs/10.1111/1468-0378.00139

Henkin, Louis.(1989). The Universality of the Concept of Human Right.The Annals of the American Academy of Political and Social Science, 506, 10-16.Retrieved from https://www.jstor.org/stable/pdf/1046650.pdf

Kohen, Ari.(2007).Introduction: The first day of class..In Defense of Human Rights(PP.6-12). OXON,OX: Routledge.

McClennen, Sophia A.\& Alexandra Schultheis Moore.(2015). The Routledge Companion to Literature and Human Rights. Commonly Human, 37-45.Retrieved from https://www.routledgehandbooks.com/doi/10.4324/9781315778372.ch2

Nayar, Pramod. K. (2012). Introduction. Writing Wrongs: The Cultural of Human Rights in India (pp.127). New Delhi, ND: Routledge.

Ngangom, Robin. S.(2007).Body. Retrieved From https://www.poetryinternationalweb.net/pi/site/poem/item/11795/auto/o/BODY

Ngangom, Robin. S. (2008).My Invented Land. Retrieved from https://www.poetryinternationalweb.net/pi/site/poem/item/11775/auto/o/MY-INVENTED-LAND

Ngangom, Robin. S. (2006). Poem for Joseph. Retrieved fromhttps://www.poetryinternationalweb.net/pi/site/poem/item/11782/auto/o/POEM-FOR-JOSEPH

Ngangom, Robin. S.(2006).To Pacha. Retrieved from https://www.poetryinternationalweb.net/pi/site/poem/item/11791/auto/o/TO-PACHA

Powell, J. Enoch.(1977).Human Rights. Journal of Medical Ethics, 3(4), 160-162.Retrieved from http://www.jstor.org/stable/27715659

Chow, Rey.(2006) Sacrifice, Mimesis, and the Theorizing of Victimhood. Representations, 94(1),131-149. Retrieved from http://www.jstor.org/stable/10.1525/rep.2006.94.1.131

Singh,Thangam Ibopishak. (2003). I Want to Be Killed By An Indian Bullet. (Robin S Ngangom,Trans.).Retrieved from https://www.poetryinternationalweb.net/pi/site/poem/item/6316/auto/o/I-WANT-TO-BE-KILLED-BYAN-INDIAN-BULLET 
Singh,Thangam Ibopishak.(2003).The Land of Half-Humans. (Robin S Ngangom,Trans.). Retrieved from https://www.poetryinternationalweb.net/pi/site/poem/item/6318/auto/o/THE-LAND-OF-THE-HALFHUMANS

Singh, Yumlembam Ibomcha. (2003). Story of A Dream. (Robin S Ngangom,Trans.) https://www.poetryinternationalweb.net/pi/site/poem/item/16112/auto/o/STORY-OF-A-DREAM

Smith, Paul.(2004).Precarious Politics[Review of the book Precarious Life: The Powers of

Mourning and Violence, by Judith Butler].Symplokē, 12(1/2), 254-26o. Available from jstorwebsite: http://www.jstor.org/stable/40550684

The Hindu Net Desk (2018, April 23). What is AFSPA, and where is it in force? The Hindu. Retrieved from https://www.thehindu.com/news/national/what-is-afspa-and-where-is-it-in-force/article23648102.ece

Thiyam, Saratchand.(2014).Sister. (Robin S Ngangom,Trans.). http://nezine.com/info/A\%2ofew\%2opoems\%20of\%2oSaratchand\%2oThiyam

Zote, Mona (2005). What Poetry Means to Ernestina in Peril.

https://www.poetryinternationalweb.net/pi/site/poem/item/13503/auto/o/WHAT-POETRY-MEANS-TOERNESTINA-IN-PERIL 